\title{
Formation of Biogenic Amines in Chicken Meat Stored under Modified Atmosphere
}

\author{
Leo Gallas ${ }^{1}$, Eva Standarová ${ }^{2}$ Iva Steinhauserová ${ }^{1}$, Ladislav Steinhauser ${ }^{1}$, \\ Lenka Vorlová ${ }^{2}$ \\ ${ }^{1}$ Department of Meat Hygiene and Technology, Faculty of Veterinary Hygiene and Ecology, \\ University of Veterinary and Pharmaceutical Sciences Brno, Czech Republic \\ ${ }^{2}$ Department of Milk Hygiene and Technology, Faculty of Veterinary Hygiene and Ecology, \\ University of Veterinary and Pharmaceutical Sciences, Brno, Czech Republic
}

\author{
Received February 13, 2009 \\ Accepted June 30, 2009
}

\begin{abstract}
The aim of the study was to investigate the effects of two modified atmospheres with a different combination of gases on selected groups of microorganisms and on concentrations of biogenic amines (BAs) in samples of poultry breast muscle. The samples were packaged under modified atmosphere $\mathrm{A}\left(75 \% \mathrm{O}_{2}\right.$ a $\left.25 \% \mathrm{CO}_{2}\right)$ or $\mathrm{B}\left(75 \% \mathrm{~N}_{2}\right.$ and $\left.25 \% \mathrm{CO}_{2}\right)$ and stored at temperatures from +2 to $+4{ }^{\circ} \mathrm{C}$ for 14 days. During the storage period, $\mathrm{O}_{2}$ concentrations in modified atmosphere $\mathrm{A}$ (MA A) decreased from the initial $74.8 \pm 0.3 \%$ to $55.9 \pm 6.6 \%$ at the end of the storage period. In all samples, counts of psychrotrophic bacteria counts, Brochothrix thermosphacta, lactic acid bacteria and coliform microorganism were determined. The tests were made on the packaging day, and then after three, nine and fourteen days of storage. At the end of the storage period, higher numbers of psychrotrophic bacteria $\left(6.5 \pm 0.7 \log _{10} \mathrm{cfu} \cdot \mathrm{g}^{-1}\right)$, Brochothrix thermosphacta $(4.8 \pm$ $\left.0.3 \log _{10} \mathrm{cfu} \cdot \mathrm{g}^{-1}\right)$ and lactic acid bacteria $\left(1.7 \pm 0.4 \log _{10} \mathrm{cfu} \cdot \mathrm{g}^{-1}\right)$ were found on samples packaged under MAA. Samples packaged under modified atmosphere B on the other hand contained higher numbers of coliform bacteria $\left(4.1 \pm 0.6 \log _{10} \mathrm{cfu} \cdot \mathrm{g}^{-1}\right)$ at the end of the storage period. In addition to microbiological indicators, concentrations of biogenic amines (putrescine, cadaverine, histamine, tyramine, spermine, spermidine and $\beta$-phenylethylamine) were also determined. In fresh samples and after three days of storage, only spermine and spermidine were found. After 9 and 14 days, also other BAs were detected. The biogenic amine totals at the end of the storage period was 60.0 $\pm 13.2 \mathrm{mg} \cdot \mathrm{kg}^{-1}$ in samples packaged under MA A and $129.0 \pm 41.3 \mathrm{mg} \cdot \mathrm{kg}^{-1}$ in samples packaged under MA B. The most abundantly represented biogenic amines in samples packaged under MA A were putrescine and spermine (49.7 and $24.8 \%$, respectively, at the end of the storage period), and putrescine and cadaverine in samples packaged under MA B (47.0 and 32.9\%, respectively, at the end of the storage period).
\end{abstract}

Poultry meat, shelf-life, microbiological quality, amines, HPLC

Poultry is a highly perishable food and the time it takes to deteriorate varies from 4 to 10 days after slaughtering, in spite of having been stored under chill systems (Phillips 1996). Modified atmosphere packaging (MAP) has become widespread (Susilu oto et al. 2003 ) in recent years to increase the shelf life of fresh chicken meat and chicken products. Various combinations of gases are used, and combinations of $\mathrm{O}_{2}, \mathrm{CO}_{2}$ and $\mathrm{N}_{2}$ are among the most frequent ones. Most of the gases used for food packaging exhibit various degrees of bacteriostatic or bactericidal effects. Shelf life of meat packaged under modified atmosphere is decisively influenced by its initial microbial contamination, the appropriateness of gas mixture used and strict cold chain compliance (Jeremiah and Gibson 2001; Farber 1991). Other gases may also be used for MAP, for instance argon (Ar) or carbon monoxide (CO), which act to stabilize the red colouring of meat and to extend its shelf-life (Sørheim et al. 1997; Sivertsvik et al. 2002). Microorganisms present in packages significantly influence sensory properties of the packaged meat, such as its colour, smell and shelf life (Balamatsia et al. 2006). In some cases, biogenic amines may be produced when certain types of microorganisms decarboxylate free amino acids (Min et al. 2004; Halász et al. 1994). Biogenic amines (especially histamine, tryptamine, $\beta$-fenylethylamine and

Address for correspondence:

Ing. Leo Gallas, PhD

Department of Meat Hygiene and Technology

University of Veterinary and Pharmaceutical Sciences Brno

Palackého 1-3, 61242 Brno, Czech Republic
Phone: +420 541562750

Fax: +420 541321230

E-mail: lgallas@vfu.cz

http://www.vfu.cz/acta-vet/actavet.htm 
tyramine) that penetrate from food to blood circulation can cause health problems of psychoactive or vasoactive nature to people. These may include increased blood pressure, onset of migraines, increased heart and respiratory rates, etc. In addition, biogenic amines (BA) are potential precursors of carcinogenic $\mathrm{N}$-nitroso compounds. It has been reported that $5-10 \mathrm{mg}$ of histamine can be considered potentially hazardous for some sensitive people. Ten $\mathrm{mg}$ are considered as a tolerable limit, $100 \mathrm{mg}$ may induce a medium toxicity and a dose of $1000 \mathrm{mg}$ histamine is highly toxic (Shalaby 1996; Karovičová and Kohajdová 2005).

The aim of our study was to make a quantitative and qualitative comparison of microflora and the formation of biogenic amines in chicken breast muscle packaged under two types of modified atmospheres ( $\mathrm{A}-25 \% \mathrm{CO}_{2}$ and $75 \% \mathrm{O}_{2}, \mathrm{~B}-25 \% \mathrm{CO}_{2}$ and $75 \% \mathrm{~N}_{2}$ ) during cold storage.

\section{Material and Methods}

Preparation of chicken meat samples and storage conditions

Fresh chicken breast meat was obtained from a local poultry slaughterhouse. A total of 80 samples from 40 broilers (ROSS 308, 40 days old) were analyzed. Samples were individually packaged into AMILEN PA/PE (Verpackungen $\mathrm{GmbH}$, Germany) bags with $60 \mu \mathrm{m}$ coat of polyamide and $20 \mu \mathrm{m}$ coat of polyethylene with ethylene-vinyl acetate (EVA) oxygen barrier layer and a gas transmission rate declared by the manufacturer for $\mathrm{O}_{2}, \mathrm{~N}_{2}$ and $\mathrm{CO}_{2}$ permeability 50,10 and $150 \mathrm{~cm}^{3} \cdot \mathrm{m}^{-2} \mathrm{~d}^{-1}$, respectively, at $23{ }^{\circ} \mathrm{C}, 0 \%$ relative humidity. Water vapour transmission rate was $3.0 \mathrm{~g} \cdot \mathrm{m}^{-2} \mathrm{~d}^{-1}$ at $23{ }^{\circ} \mathrm{C}, 85 \%$ relative humidity. Weight per area was $80 \mathrm{~g} \cdot \mathrm{m}^{-2}$, tensile strength at break $45 \%$ longitudinally and $35 \%$ transversally.

Meat samples were individually packaged on a Vac-Star S 223 GX (Frimark CZ Ltd., Czech Republic). Half of the samples were packed in modified atmosphere A $\left(25 \% \mathrm{CO}_{2}\right.$ and $\left.75 \% \mathrm{O}_{2}\right)$ and second half in modified atmosphere $\mathrm{B}\left(25 \% \mathrm{CO}_{2}\right.$ and $\left.75 \% \mathrm{~N}_{2}\right)$. The air was first evacuated from the packages $(99 \%$ vacuum $)$ which were then flushed once prior to the final treatment with the gas mixture. Food grade $\mathrm{CO}_{2}-\mathrm{O}_{2}$ and $\mathrm{CO}_{2}-\mathrm{N}_{2}$ (Linde Gas, Brno, Czech Republic) were used. All the plastic bags were heat-sealed. Packages were placed in isothermal boxes and transported from the poultry slaughterhouse to cold storage at our institute. All the packages containing poultry meat samples were stored chilled at $+2-4{ }^{\circ} \mathrm{C}$. The temperature was recorded six times an hour using the LOGGER S3120 digital thermometer (Comet System Ltd., Rožnov pod Radhoštěm, Czech Republic).

Sampling was carried out at predetermined time intervals, i.e. on day 0 (control - day of packaging), and on days 3, 9 and 14 after packaging.

Head space gas analysis

The head space gas composition $\left(\% \mathrm{O}_{2}\right)$ was assessed in triplicate by using an oxygen analyzer (OxiMETR, VEIT Electronics, Brno, Czech Republic). An aliquot $(20 \mathrm{ml})$ of the head space gas was collected with a syringe inserted through the cover film. Before the syringe was inserted, a foam rubber septum (VEIT Electronics, Brno, Czech Republic) was added to the cover film to avoid introduction of false atmosphere into the gas analyzer. Mean values were used for the statistical data analysis.

Microbiological analyses

Microbial contamination of chicken breast muscle was evaluated by determining the psychrotrophic bacteria count, Brochothrix thermosphacta count, lactic acid bacteria count and total coliform bacteria count.

The psychrotrophic bacteria count was determined on Plate Count Agar (CM0463, Oxoid Ltd., Basingstoke, Hampshire, UK), aerobically, 10 days at $6.5 \pm 1{ }^{\circ} \mathrm{C}$, in accordance with the ISO 17410:2001 guidelines. Brochothrix thermosphacta was cultivated on STAA Agar Base (CM0881, Oxoid) aerobically for $48 \pm 4 \mathrm{~h}$ at $23 \pm 1{ }^{\circ} \mathrm{C}$ in accordance with the ISO 13722:1998 guidelines. The quantification of lactic acid bacteria (LAB) was performed on de Man, Rogosa, Sharpe agar (MRS Agar, CM0361, Oxoid) anaerobically for $72 \pm 3 \mathrm{~h}$ at 30 $\pm 1{ }^{\circ} \mathrm{C}$, in accordance with the ISO 13721:1995 guidelines. The total coliform bacteria count was determined by detection on Oxoid Brilliance E. coli/coliform Selective Agar (CM1046, Oxoid) aerobically for $24 \pm 2 \mathrm{~h}$ at $37 \pm$ $1{ }^{\circ} \mathrm{C}$. All analyses were performed in duplicate. The number of formed colonies was counted and reported as $\log _{10}$ of $\mathrm{cfu} \cdot \mathrm{g}^{-1}$ for every sample.

Measurement of biogenic amines

Biogenic amines (putrescine (PUT), cadaverine (CAD), histamine (HIS), $\beta$-phenylethylamine (PHE), tyramine (TYR), spermidine (SPD) and spermine (SPN)) were determined by pre-column dansylchloride derivatization HPLC as described by Paulsen et al. (1997). Concentrations of biogenic amines were determined by HPLC using an Alliance 2695 liquid chromatofigure (Waters, USA) with a 2475 fluorescence detector and a PDA 2996 detector. The separation was performed using a Polaris C18 column (Varian, USA) with reversion phase $4.6 \times$ $150 \mathrm{~mm}$, stationary phase grain size $3 \mu \mathrm{m}$ and the column temperature of $35^{\circ} \mathrm{C}$. Amine dansylderivates were quantified by the external standard method using Empower software (Waters, USA). 
Biogenic amines were determined in chicken breast muscle. All analyses were performed in duplicate. Mean values were used for the statistical data analysis.

Statistical analysis

Results of microbiological and chemical analyses are reported as mean values \pm standard deviation (s.d.). Microbiological counts $\left(\log _{10} \mathrm{cfu} \cdot \mathrm{g}^{-1}\right), \% \mathrm{O}_{2}$ and content of biogenic amines were analysed. Student's $t$-test was applied to determine the differences between individual storage days. The 0.05 level of significance was used. Correlation coefficients of microbiological counts and biogenic amines amount were generated using the Pearson's correlation coefficient. Statistical data analyses were conducted using the statistical programme STATISTICA Cz (Statsoft, Czech Republic).

\section{Results}

Temperature and $\mathrm{O}_{2}$ concentration in modified atmosphere

The mean temperature throughout the meat sample storage period was $3.2 \pm 0.7^{\circ} \mathrm{C}$. The $\mathrm{O}_{2}$ levels in modified atmosphere $\mathrm{A}$ at the time of packaging and at the end of the 14-day period were $74.8 \pm 0.3 \%$ and $55.9 \pm 6.6 \%$, respectively. In modified atmosphere $\mathrm{B}$, the $\mathrm{O}_{2}$ levels at the beginning and at the end of the storage period were $0.4 \pm 0.2 \%$ and $0.7 \pm 0.3 \%$, respectively (Table 1).

Table 1. Changes in $\mathrm{O}_{2}$ concentrations [\%] during storage time in modified atmospheres $\mathrm{A}$ and $\mathrm{B}$ (mean \pm s.d.)

\begin{tabular}{|c|c|c|c|c|}
\hline & Day 0 & Day 3 & Day 9 & Day 14 \\
\hline A & $74.8 \pm 0.3$ & $65.9 \pm 9.3$ & $58.2 \pm 8.9$ & $55.9 \pm 6.6$ \\
\hline B & $0.4 \pm 0.2$ & $0.6 \pm 0.2$ & $0.6 \pm 0.4$ & $0.7 \pm 0.3$ \\
\hline
\end{tabular}

\section{Microbiological indicators}

Microorganism counts of meat samples packaged under the two types of modified atmosphere (MA) are given in Table 2. The initial psychrotrophic bacteria counts were $3.1 \log _{10} \mathrm{cfu} \cdot \mathrm{g}^{-1}$ in both sets of samples. After three days of storage, their counts decreased slightly to 2.7 and $2.8 \log _{10} \mathrm{cfu} \cdot \mathrm{g}^{-1}$ in MA A (with $\mathrm{O}_{2}$ ) and MA B, respectively. From day 3 until the end of the storage period, the numbers of psychrotrophic bacteria grew continuously to reach 6.5 and $5.8 \log _{10} \mathrm{cfu} \cdot \mathrm{g}^{-1}$ in MA A (with $\mathrm{O}_{2}$ ) and MA B, respectively. Neither at the beginning nor during the storage period were there any statistical differences in psychrotrophic bacteria counts between samples in MA A and MA B.

Table 2. Changes in microbiological indicators of chicken breast during storage under modified atmospheres $\mathrm{A}$ and $\mathrm{B}\left[\log _{10} \mathrm{cfu} \cdot \mathrm{g}^{-1}\right]($ mean \pm s.d. $)$

\begin{tabular}{|l|c|c|c|c|c|}
\hline Microorganism & $\begin{array}{c}\text { Modified } \\
\text { atmosphere }\end{array}$ & Day 0 & Day 3 & Day 9 & Day 14 \\
\hline Psychrotrophic bacteria & A & $3.1 \pm 0.2$ & $2.7 \pm 0.4$ & $4.4 \pm 0.5$ & $6.5 \pm 0.7$ \\
\hline & B & $3.1 \pm 0.6$ & $2.8 \pm 0.5$ & $4.8 \pm 0.6$ & $5.8 \pm 0.8$ \\
\hline Brochothrix thermosphacta & A & $2.2 \pm 0.3$ & $3.2 \pm 0.2$ & $3.5 \pm 0.2$ & $4.8 \pm 0.3$ \\
\hline & B & $1.2 \pm 0.4$ & $1.1 \pm 0.5$ & $1.4 \pm 0.3$ & $2.5 \pm 0.2$ \\
\hline Lactic acid bacteria & A & $1.3 \pm 0.3$ & $1.0 \pm 0.1$ & $0.7 \pm 0.2$ & $1.7 \pm 0.4$ \\
\hline & B & $1.6 \pm 0.2$ & $2.1 \pm 0.7$ & $1.0 \pm 0.3$ & $0.6 \pm 0.2$ \\
\hline Coliform microorganisms & A & n.d. & $1.1 \pm 0.3$ & $1.1 \pm 0.6$ & $1.9 \pm 0.4$ \\
\hline & B & n.d. & $0.5 \pm 0.2$ & $2.7 \pm 0.3$ & $4.1 \pm 0.6$ \\
\hline
\end{tabular}

n.d. not detected

The initial lactic acid bacteria (LAB) count was $1.3 \log _{10} \mathrm{cfu}^{-\mathrm{g}^{-1}}$ in the MA A set of samples. The LAB counts in MA A set of samples decreased over the period of storage. The minimum count of $0.7 \log _{10} \mathrm{cfu} \cdot \mathrm{g}^{-1}$ was recorded on day 9 . Towards the end of the storage period, LAB counts of the MA A set of samples increased to $1.7 \log _{10} \mathrm{cfu} \cdot \mathrm{g}^{-1}$. The 
initial LAB count in the MA B set of samples was $1.6 \log _{10} \mathrm{cfu} \cdot \mathrm{g}^{-1}$. After three days of storage, their numbers peaked at $2.1 \log _{10} \mathrm{cfu} \cdot \mathrm{g}^{-1}$ and from then continued to decrease to reach the end-of-storage level of $0.6 \log _{10} \mathrm{cfu} \cdot \mathrm{g}^{-1}$. In spite of the variations in LAB counts, no significant differences between samples in MA A and MA B sets were found at the beginning of or during the storage period.

The initial Brochothrix thermosphacta counts in the MA A and B sets of samples were 2.2 and $1.2 \log _{10} \mathrm{cfu} \cdot \mathrm{g}^{-1}$, respectively. The numbers of Brochothrix thermosphacta gradually increased in both MAA and MAB sets to reach the final 4.8 and $2.5 \log _{10} \mathrm{cfu} \cdot \mathrm{g}^{-1}$, respectively, Brochothrix thermosphacta counts on storage days 3, 9 and 14 were significantly higher in samples stored under MA A $(p<0.05)$.

No coliform microorganisms were found in any of the samples at the beginning of storage. After three days of storage, however, some coliform microorganisms were found under both MA A and MA B, and their numbers grew from then onwards until reaching the final level of 1.9 and $4.1 \log _{10} \mathrm{cfu} \cdot \mathrm{g}^{-1}$, respectively. On days 9 and 14 , fewer coliform microorganisms were found under MAA, and the difference was significant $(p<0.05)$.

\section{Biogenic amine content}

Contents of biogenic amines (BAs) found in poultry meat samples packaged under the two types of modified atmosphere (MA) are given in Table 3.

Table 3. Changes in biogenic amines concentrations on chicken breast during storage under modified atmospheres A and B [mg. $\left.\mathrm{kg}^{-1}\right]$ (mean \pm s.d.)

\begin{tabular}{|c|c|c|c|c|c|c|c|c|}
\hline Day & $\begin{array}{c}\text { modified } \\
\text { atmosphere }\end{array}$ & PUT & CAD & HIM & TYM & SPM & SPD & Total \\
\hline 0 & A & n.d. & n.d. & n.d. & n.d. & $17.8 \pm 0.6$ & $7.5 \pm 0.7$ & $25.3 \pm 0.7$ \\
\hline & B & n.d. & n.d. & n.d. & n.d. & $17.7 \pm 0.6$ & $7.6 \pm 0.8$ & $25.2 \pm 0.8$ \\
\hline 3 & A & n.d. & n.d. & n.d. & n.d. & $17.3 \pm 0.6$ & $7.7 \pm 0.9$ & $25.0 \pm 0.7$ \\
\hline & B & n.d. & n.d. & n.d. & n.d. & $17.9 \pm 0.4$ & $7.3 \pm 1.3$ & $25.2 \pm 1.5$ \\
\hline 9 & A & $26.4 \pm 4.8$ & $8.5 \pm 8.4$ & n.d. & n.d. & $16.0 \pm 1.0$ & $6.1 \pm 0.9$ & $57.1 \pm 13.1$ \\
\hline & B & $72.5 \pm 63.8$ & $21.7 \pm 16.6$ & $1.8 \pm 1.4$ & $1.9 \pm 1.5$ & $16.5 \pm 0.7$ & $6.3 \pm 0.8$ & $119.8 \pm 75.6$ \\
\hline 14 & A & $29.8 \pm 10.9$ & $9.5 \pm 4.1$ & n.d. & n.d. & $14.9 \pm 1.4$ & $5.9 \pm 1.6$ & $60.0 \pm 13.2$ \\
\hline & B & $60.6 \pm 30.7$ & $42.4 \pm 30.6$ & $1.6 \pm 1.2$ & $3.2 \pm 3.1$ & $15.3 \pm 0.8$ & $6.4 \pm 1.4$ & $129.0 \pm 41.3$ \\
\hline
\end{tabular}

n.d. not detected

At the beginning of storage and on day 3, no putrescine was detected in any of the samples. After nine days of storage, $26.4 \mathrm{mg} \cdot \mathrm{kg}^{-1}$ putrescine was detected in samples stored under MA A, and that level slightly increased by the end of the storage period to 29.8 $\mathrm{mg} \cdot \mathrm{kg}^{-1}$. After nine days of storage, putrescine was also detected in MA B samples at 72.5 $\mathrm{mg} \cdot \mathrm{kg}^{-1}$, but that level decreased by the end of the storage period to $60.6 \mathrm{mg} \cdot \mathrm{kg}^{-1}$. After days 9 and 14 of storage, samples stored under MA B contained significantly more putrescine than MA A samples $(p<0.05)$.

At the beginning of storage and on day 3, no cadaverine was detected in any of the samples. After nine days of storage, $8.5 \mathrm{mg} \cdot \mathrm{kg}^{-1}$ cadaverine was detected in samples stored under MA A, and that level remained practically unchanged $\left(9.5 \mathrm{mg} \cdot \mathrm{kg}^{-1}\right)$ until the end of the storage period. After nine days of storage, cadaverine was also detected in MA B samples at $21.7 \mathrm{mg} \cdot \mathrm{kg}^{-1}$, and that level increased by the end of the storage period to 42.4 $\mathrm{mg} \cdot \mathrm{kg}^{-1}$. After days 9 and 14 of storage, cadaverine contents in samples stored under MA B were significantly higher than those in MA A samples $(p<0.05)$.

In samples stored under MA A, no histamine was found either at the beginning of or during the storage period. In samples stored under MA B, $1.4 \mathrm{mg} \cdot \mathrm{kg}^{-1}$ histamine 
was detected after nine days of storage, and that level remained practically unchanged $\left(1.2 \mathrm{mg} \cdot \mathrm{kg}^{-1}\right)$ until the end of the storage period $(p<0.05)$.

Spermine was detected over the entire period of storage between 14.9 and $17.9 \mathrm{mg} \cdot \mathrm{kg}^{-1}$ in both types of sample packaging. The slight decrease in spermine levels on days 9 and 14 of storage was non-significant.

Spermidine contents in samples developed very much like those of spermine. At the beginning and on day 3 of the storage period, levels between 7.3 and $7.7 \mathrm{mg} \cdot \mathrm{kg}^{-1}$ were found in both of the atmospheres used, and a decrease on days 9 and 14 of storage to levels between 5.9 and $6.4 \mathrm{mg} \cdot \mathrm{kg}^{-1}$.

In samples stored under MA A, tyramine was not found either at the beginning of or during the storage period. In samples stored under MA B, $1.5 \mathrm{mg} \cdot \mathrm{kg}^{-1}$ tyramine was detected after nine days of storage, and that level increased to $3.2 \mathrm{mg} \cdot \mathrm{kg}^{-1}$ by the end of the storage period.

$\beta$-phenylethylamine was not found either at the beginning of or during the storage period in any of the samples.

At the beginning of storage and on day 3 of storage, total biogenic amines in all samples were around $25 \mathrm{mg} \cdot \mathrm{kg}^{-1}$, and they consisted only of spermine and spermidine. After three days of storage, BA contents increased to $57.1 \mathrm{mg} \cdot \mathrm{kg}^{-1}$ and $119.8 \mathrm{mg} \cdot \mathrm{kg}^{-1}$ in MA A and MA B, respectively. At the end of storage, BA levels were $60.0 \mathrm{mg} \cdot \mathrm{kg}^{-1}$ and $129.0 \mathrm{mg} \cdot \mathrm{kg}^{-1}$ in MA A and MA B, respectively. After 9 and 14 days of storage, the most abundantly represented biogenic amines in samples packaged under MA A were putrescine and spermine (49.7 and $24.8 \%$, respectively, at the end of storage period), and putrescine and cadaverine in samples packaged under MA B (47.0 and 32.9\%, respectively, at the end of storage period). After days 9 and 14 of storage, samples stored under MA B had significantly higher contents of biogenic amines than samples stored under MAA $(p<0.05$ and $p<0.001$, respectively).

Table 4 demonstrates correlation between microbiological indicators and biogenic amines contents.

Table 4. Correlation coefficients of microbiological counts and biogenic amines amount in chicken breast during storage under modified atmospheres A and B (only significant coefficients, $p<0.05$ )

\begin{tabular}{|l|c|c|c|c|c|c|c|c|}
\hline Day & $\begin{array}{c}\text { Modified } \\
\text { atmosphere }\end{array}$ & PUT & CAD & HIM & TYM & SPM & SPD & Total \\
\hline $\begin{array}{l}\text { Psychrotrophic } \\
\text { bacteria }\end{array}$ & A & 0.7658 & 0.5050 & - & - & -0.5979 & -0.5170 & 0.7027 \\
\hline & $\mathrm{B}$ & 0.5737 & 0.5488 & 0.3687 & 0.6022 & -0.7980 & - & 0.6366 \\
\hline $\begin{array}{l}\text { Brochothrix } \\
\text { thermosphacta }\end{array}$ & $\mathrm{A}$ & 0.3679 & - & - & - & - & - & 0.3694 \\
\hline & $\mathrm{B}$ & - & - & - & 0.3663 & -0.4608 & - & - \\
\hline $\begin{array}{l}\text { Lactic acid } \\
\text { bacteria }\end{array}$ & $\mathrm{A}$ & - & - & - & - & - & - & - \\
\hline & $\mathrm{B}$ & -0.4353 & - & -0.3148 & -0.3508 & - & - & -0.3989 \\
\hline $\begin{array}{l}\text { Coliform } \\
\text { microorganisms }\end{array}$ & $\mathrm{A}$ & 0.3151 & - & - & - & - & -0.3448 & - \\
\hline & $\mathrm{B}$ & 0.6178 & 0.6020 & 0.4582 & 0.6153 & -0.8118 & -0.3585 & 0.6895 \\
\hline
\end{tabular}

\section{Discussion}

Modified atmosphere packaging uses a combination of specific gases, which can enhance the shelf life of retail meat products (Jeremiah and Gibson 2001). Carbon dioxide is the major anti-microbial factor of MAP. The inhibitory effect is seen as an increase in the lag 
phase and generation time during the logarithmic phase of growth of the microbes (Reddy et al. 1992). A minimum $\mathrm{CO}_{2}$ concentration of $20-30 \%$ is necessary to exhibit the inhibitory effect (Stiles 1991). Carbon dioxide is most effective in foods where the normal spoilage organisms consist of aerobic, gram-negative psychrotrophic bacteria (Phillips 1996). Besides the direct inhibitory action of $\mathrm{CO}_{2}$ in its gaseous form in modified atmosphere, $\mathrm{CO}_{2}$ also exhibits inhibitory action in its dissolved form. Devlieghere and Debevere (2000) described the effect of dissolved $\mathrm{CO}_{2}$ on various representatives of gram-positive and gram-negative spoilage microbial flora. The effectiveness of carbon dioxide as an antimicrobial agent is not universal and depends on the microbial flora present and the product characteristics. Oxygen affects the microbial flora on packaged meat. Generally, it stimulates the growth of aerobic bacteria and inhibits the growth of anaerobes (Phillips 1996). Nitrogen is used to replace oxygen in modified atmosphere packaged products to prevent rancidity and inhibit the growth of aerobic microbes (Farber 1991; Gill et al. 1990).

Microflora composition of meat packaged under modified atmosphere with minimum levels of oxygen concentrations is considerably different. Major part of the specific microflora are psychrotrophic lactic acid bacteria, particularly members of the genera Carnobacterium, Lactobacillus and Leuconostoc (Gram et al. 2002; Björkroth et al. 2000; Borch et al. 1996). In chilled poultry meat packaged under MA, large populations of Brochothrix thermosphacta are also frequently found (Pin et al. 2002).

Initial concentrations of psychrotrophic aerobic microflora in our samples were around $3.1 \log _{10} \mathrm{cfu} \cdot \mathrm{g}^{-1}$, which is near the lower limit of recently published values $(2.8$ to $4.7 \log _{10} \mathrm{cfu} \cdot \mathrm{g}^{-1}$ ) (Chouliara et al. 2008; Charles et al. 2006). That means that our material was of good quality from the hygienic point of view. The absence of coliform microflora, too, is indicative of very good hygienic profile of our samples. The slight decrease in the psychrotrophic bacteria counts after three days of storage in samples from both of the two modified atmospheres can be explained by the synergy effect of a heat shock and modified atmosphere. The endpoint values correspond to those obtained in similar studies in other countries (Malicki et al. 2006; Charles et al. 2006).

Brochothrix thermosphacta $(\mathrm{G}+$, facultatively anaerobic) is one of the most important spoilage microorganisms in poultry meat either stored in a simple anaerobic packaging or under MA packaging. Its spoilage-causing activity is most noticeable in an ambient with lower concentrations of oxygen and higher concentrations of $\mathrm{CO}_{2}$. It can, however, grow very well in the vacuum and other types of environment. Jimenez et al. (1997) reported $B$. thermosphacta counts after a 14-day storage of poultry breast muscle at $4{ }^{\circ} \mathrm{C}$ at the level of $6.73 \log _{10} \mathrm{cfu} \cdot \mathrm{g}^{-1}\left(\mathrm{MA} 70 \% \mathrm{~N}_{2}\right.$ and $\left.30 \% \mathrm{CO}_{2}\right)$ and $7.49 \log _{10} \mathrm{cfu} \cdot \mathrm{g}^{-1}\left(\mathrm{MA} 70 \% \mathrm{CO}_{2}\right.$ and $30 \% \mathrm{~N}_{2}$ ). Their values were markedly higher than our results probably because initial concentrations of $B$. thermosphacta in their experimental material were also markedly higher (3.95 and $4.25 \log _{10} \mathrm{cfu} \cdot \mathrm{g}^{-1}$ ) than those in our experiment. Chouliara et al. (2008) reported the following $B$. thermosphacta counts in poultry breast muscle after 15-day storage at the temperature of $4{ }^{\circ} \mathrm{C}$ : MA $1\left(70 \% \mathrm{~N}_{2}\right.$ and $\left.30 \% \mathrm{CO}_{2}\right) 7.03 \pm 0.43 \log _{10} \mathrm{cfu} \cdot \mathrm{g}^{-1}$, MA $2\left(70 \% \mathrm{CO}_{2}\right.$ and $\left.30 \% \mathrm{~N}_{2}\right) 7.21 \pm 0.51 \log _{10} \mathrm{cfu}^{2} \cdot \mathrm{g}^{-1}$. Our counts are lower, particularly thanks to lower initial B. thermosphacta counts (Table 2) and a lower temperature of storage $\left(3.2 \pm 0.7^{\circ} \mathrm{C}\right)$.

In similarly designed experiments, some other authors (Jimenez et al. 1997; Chouliara et al. 2008; Vihavainen et al. 2007) reported lactacidogenic microflora counts higher than our results by an order of magnitude (about $10^{6}-10^{8} \mathrm{cfu} \cdot \mathrm{g}^{-1}$ after two-week storage), attributable especially to markedly higher initial levels of LAB in their experiment. In spite of different ratios between gases in the two MA, no significant differences in lactic acid bacteria counts were found during our experiment. The decline and subsequent increase in the number of LAB during storage may be due to different input numbers of LAB in 
packaged meat. It is also possible that the decrease corresponds to the death of mesophilic $\mathrm{LAB}$, with a consequent increase of psychrotrophic strains of LAB (Vihavajnen et al. 2007; Björkroth et al. 2000).

Coliform microflora counts depend largely on the conditions prevailing during slaughter. Jimenez et al. (2003) reported that $11.3 \%$ of carcasses showed faecal material and $5.2 \%$ showed bile on the surface after the evisceration step. The absence of Escherichia coli over the entire period of storage or of other coliform microflora at the beginning of storage is indicative of a good hygienic profile of samples (Zeitoun et al. 1994). The increase in coliform microflora abundance is due to the adaptation and development of its psychrotrophic members. The abundance of $E$. coli and of other coliform microflora may serve as a good indicator of cold storage chain disruption. The significantly lower numbers of coliform microorganisms in samples stored under MA A can be explained by a synergic inhibitory effect of low temperature and high $\mathrm{O}_{2}$ and $\mathrm{CO}_{2}$ concentrations. In their study of various types of atmosphere, Chouliara et al. (2008) reported the following Enterobacteriaceae counts in poultry breast muscle after 15 -day storage at $4{ }^{\circ} \mathrm{C}$ : MA 1 $\left(70 \% \mathrm{~N}_{2}\right.$ and $\left.30 \% \mathrm{CO}_{2}\right) 7.02 \pm 0.52 \log _{10} \mathrm{cfu}^{-1} \mathrm{~g}^{-1}$, MA $2\left(70 \% \mathrm{CO}_{2}\right.$ and $\left.30 \% \mathrm{~N}_{2}\right) 6.71 \pm 0.49$ $\log _{10} \mathrm{cfu}^{2} \cdot \mathrm{g}^{-1}$; simple aerobic packaging (control) - the last relevant value after 9 days of

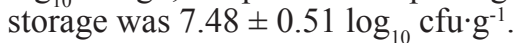

At the beginning and during the first three days of storage, samples stored under both MA A and MA B contained only spermine and spermidine, which occur naturally in the organism. Concentrations of these biogenic amines decrease over the storage period because they serve as a source of nitrogen to the microorganisms present there. In their experiments with breast muscle tissue, Silva and Glória (2002) reported practically the same initial contents of spermine $\left(17.9 \mathrm{mg} \cdot \mathrm{kg}^{-1}\right)$ and spermidine $\left(7.3 \mathrm{mg} \cdot \mathrm{kg}^{-1}\right)$ as those recorded in our study. The concentrations they found after 15 days of storage (SPM 11.2 $\mathrm{mg} \cdot \mathrm{kg}^{-1}$ and SPD $8.7 \mathrm{mg} \cdot \mathrm{kg}^{-1}$ ) also correspond to our findings. Balamatsia et al. (2006), on the other hand, found the same initial content of spermidine $\left(7.9 \mathrm{mg} \cdot \mathrm{kg}^{-1}\right)$ in breast muscle tissue in simple (aerobic) packaging but higher initial contents $\left(13.2 \mathrm{mg} \cdot \mathrm{kg}^{-1}\right)$ in samples packaged under MA $\left(30 \% \mathrm{CO}_{2}\right.$ and $\left.70 \% \mathrm{~N}_{2}\right)$. They also reported markedly higher initial contents of spermine ( 53.3 and $56.3 \mathrm{mg} \cdot \mathrm{kg}^{-1}$ ) than those found in our study. Spermine and spermidine were the only biogenic amines detected at the beginning of the storage period and after 3-day storage. This may suggest that the development of microflora with decarboxylase activity began only after that period, because other biogenic amines are produced by microbial action. In samples stored under MA A, no tyramine was found either at the beginning of or during the entire storage period. In samples stored under MA $\mathrm{B}$, tyramine was found only after nine days of storage, and in very small quantities only. Silva and Glória (2002) also reported the first detection of tyramine $\left(17.4 \mathrm{mg} \cdot \mathrm{kg}^{-1}\right)$ in breast muscle only at the end of storage (after a 15-day storage period). Balamatsia et al. (2006), on the other hand, found low levels (tenths of milligrams) of tyramine already in the input material, and its concentrations increased over the entire period of storage to reach $4 \mathrm{mg} \cdot \mathrm{kg}^{-1}$ (simple aerobic packaging) and $8.9 \mathrm{mg} \cdot \mathrm{kg}^{-1}\left(\mathrm{MA}\right.$ of $30 \% \mathrm{CO}_{2}$ and $70 \% \mathrm{~N}_{2}$ ) at the end of a 17-day period of storage. Because tyramine is produced mainly by coliform microflora and lactic acid bacteria (Min et al. 2004), the absence of tyramine is indicative of good initial microbiological conditions of our samples and good inhibitory effects of MAA on those types of bacteria.

In samples stored under MA A, no histamine was found either at the beginning of or during the entire storage period. In samples stored under MA B, histamine was found only after nine days of storage, and then in minimum quantities only. Silva and Glória (2002) also reported the first detection of histamine $\left(10.3 \mathrm{mg} \cdot \mathrm{kg}^{-1}\right)$ in breast muscle only at the end of storage (after a 15-day storage period). Balamatsia et al. (2006) first detected histamine (in units of milligrams per $\mathrm{kg}$ ) after 11 days of storage. After 14 days of storage 
in simple aerobic packaging, the authors reported $8.6 \mathrm{mg} \cdot \mathrm{kg}^{-1}$ histamine; contrasting with it were surprisingly higher histamine concentrations $\left(14.5 \mathrm{mg} \cdot \mathrm{kg}^{-1}\right)$ after the same period of storage under MA $\left(30 \% \mathrm{CO}_{2}\right.$ a $\left.70 \% \mathrm{~N}_{2}\right)$. Because histamine in significant quantities is produced by some members of Enterobacteriaceae and by lactic acid bacteria (Min et al. 2004), the absence of histamine during storage and its non-significant concentrations at the end of the storage period are indicative of a good hygienic profile of input material and good inhibitory effects of MA.

From storage day 9 onward, putrescine and cadaverine were detected in samples packaged under both MA A and MA B. Although literary sources differ somewhat from one another about what microorganisms are mainly responsible for the production of these BAs, members of Enterobacteriaceae and some other microorganisms seem to be responsible for the production of cadaverine, and pseudomonads mainly for putrescine. While Silva and Glória (2002) reported the first detection of putrescine $\left(20.4 \mathrm{mg} \cdot \mathrm{kg}^{-1}\right)$ and cadaverine $\left(4.3 \mathrm{mg} \cdot \mathrm{kg}^{-1}\right)$ at the time when it was also detected by the authors of the present study, i.e. only after a 15-day storage period, Balamatsia et al. (2006) detected the two BAs in initial samples already and their concentrations were at the levels of tens of milligrams per $\mathrm{kg}$. After 14 days of storage, they reported putrescine and cadaverine concentrations of $250-300 \mathrm{mg} \cdot \mathrm{kg}^{-1}$ and $120-160 \mathrm{mg} \cdot \mathrm{kg}^{-1}$, respectively.

Biogenic amine total is a sum of all detected BAs. The BA totals can therefore be viewed as a result of all the individual influences affecting the production of individual BAs, which is also the reason why the value varies so much from one input to another. At the beginning of the storage period and in its first three days, the BA total of 25.2 to $25.3 \mathrm{mg} \cdot \mathrm{kg}^{-1}$ consisted of naturally occurring BAs, i.e. spermine and spermidine. From day 9 onwards, BAs of microbial origin (mainly putrescine and cadaverine) were produced in samples stored under both MAs, which corresponded with microflora development. While BA totals in samples stored under MA A at the end of the storage period were $60.0 \pm 13.2$ $\mathrm{mg} \cdot \mathrm{kg}^{-1}$, concentrations twice as high were found in samples stored under MA B (129.0 $\left.\pm 41.3 \mathrm{mg} \cdot \mathrm{kg}^{-1}\right)$. Balamatsia et al. (2006) reported BA totals of about $500 \mathrm{mg} \cdot \mathrm{kg}^{-1}$ for simple aerobic packaging and about $400 \mathrm{mg} \cdot \mathrm{kg}^{-1}$ in samples packaged under MA $(30 \%$ $\mathrm{CO}_{2}$ and $70 \% \mathrm{~N}_{2}$ ) after 14-day storage. Vinci and Antonelli (2002) found the BA total of $237.2 \mathrm{mg} \cdot \mathrm{kg}^{-1}$ in poultry meat stored for 15 days at $4 \pm 1{ }^{\circ} \mathrm{C}$. In their study of breast muscle samples stored for 15 days, Silva and Glória (2002) on the other hand reported $72.3 \mathrm{mg} \cdot \mathrm{kg}^{-1}$, which corresponds to values found in our study.

With respect to the production of biogenic amines in our study, better results were obtained with modified atmosphere $\mathrm{A}\left(75 \% \mathrm{O}_{2}\right.$ and $\left.25 \% \mathrm{CO}_{2}\right)$, where the mean biogenic amine concentration at the end of storage was $60 \mathrm{mg} \cdot \mathrm{kg}^{-1}$, whereas the mean biogenic amine concentration in samples packaged under modified atmosphere $\mathrm{B}\left(75 \% \mathrm{~N}_{2}\right.$ and $25 \%$ $\mathrm{CO}_{2}$ ) was more than twice as high $\left(129 \mathrm{mg} \cdot \mathrm{kg}^{-1}\right)$. This marked difference may be connected with the development of coliform microflora in samples packaged under modified atmosphere B.

\section{Tvorba biogenních aminů u kuřecího masa skladovaného v modifikované atmosféře}

Cílem práce bylo sledování vlivu dvou modifikovaných atmosfér s rozdílným složením plynů na vybrané skupiny mikroorganismů a na obsah biogenních aminů (BAs) u vzorků kưrecí prsní svaloviny. Vzorky byly zabaleny do modifikované atmosféry A $\left(75 \% \mathrm{O}_{2}\right.$ a $\left.25 \% \mathrm{CO}_{2}\right)$ a $\mathrm{B}\left(75 \% \mathrm{~N}_{2}\right.$ and $\left.25 \% \mathrm{CO}_{2}\right)$ a byly skladovány při teplotě +2 až $+4{ }^{\circ} \mathrm{C}$ po dobu čtrnácti dnů. $\mathrm{V}$ průběhu skladování se snižovala koncentrace $\mathrm{O}_{2} \mathrm{v}$ modifikované atmosfére A (MA A) z výchozí koncentrace 74,8 \pm 0,3\% až na 55,9 \pm 6,6\% na konci skladování. U všech vzorků se stanovovaly počty psychrotrofních bakterií, Brochothrix thermosphacta, bakterií mléčného kvašení a koliformních mikroorganismů. Analýza probíhala v den 
zabalení a dále po třech, devíti a čtrnácti dnech skladování. Vyšší počty psychrotrofních bakterií $\left(6,5 \pm 0,7 \log _{10} \mathrm{cfu} \cdot \mathrm{g}^{-1}\right)$, Brochothrix thermosphacta $\left(4,8 \pm 0,3 \log _{10} \mathrm{cfu} \cdot \mathrm{g}^{-1}\right)$ a bakterií mléčného kvašení $\left(1,7 \pm 0,4 \log _{10} \mathrm{cfu} \cdot \mathrm{g}^{-1}\right)$ obsahovaly na konci skladování vzorky balené do MA A. Oproti tomu vzorky balené do modifikované atmosféry B (MA B) obsahovaly na konci skladování vyšší počty koliformních mikroorganismů $\left(4,1 \pm 0,6 \log _{10} \mathrm{cfu} \cdot \mathrm{g}^{-1}\right)$. Společně s mikrobiologickými parametry se stanovoval obsah biogenních aminů (putrescin, kadaverin, histamin, tyramin, spermin, spermidin, $\beta$-phenylethylamin). U čerstvých vzorků a po třech dnech skladování byly stanoveny pouze spermin a spermidin. Po devíti a čtrnácti dnech skladování byly detekovány i další BAs. Celkové množství biogenních aminů činilo na konci skladování $60,0 \pm 13,2 \mathrm{mg} \cdot \mathrm{kg}^{-1} \mathrm{u}$ vzorků balených do MA A a 129,0 $\pm 41,3 \mathrm{mg} \cdot \mathrm{kg}^{-1} \mathrm{u}$ vzorků balených do MA B. Nejvíce zastoupenými biogenními aminy byly u vzorků skladovaných v MA A putrescin a spermin (49,7 a 24,8\% na konci skladování); zatím co u vzorků skladovaných v MA B to byli putrescin a kadaverin (47,0 a 32,9\% na konci skladování).

\section{Acknowledgement}

This experimental study was supported by the Ministry of Education, Youth and Sports of the Czech Republic (Research plan MSM6215712402).

The authors are also grateful to all the staff of PROMT Modrice, a.s., for their kind help in processing the chicken broilers meat and their overall technical assistance.

\section{References}

Balamatsia CC, Paleologos EK, Kontominas MG, Savvaidis IN 2006: Correlation between microbial flora, sensory changes and biogenic amines formation in fresh chicken meat stored aerobically or under modified atmosphere packaging at 4 degrees $\mathrm{C}$ : possible role of biogenic amines as spoilage indicators. Anton Leeuw Int J G 89: 9-17

Björkroth KJ, Geisen R, Schillinger U, Weiss N, De Vos P, Holzapfel WH, Korkeala HJ, Vandamme P 2000: Characterization of Leuconostoc gasicomitatum sp. nov., associated with spoiled raw tomato-marinated broiler meat strips packaged under modified-atmosphere conditions. Appl Environ Microb 66: 3764-3772

Borch E, Kantmuermans ML, Blixt Y 1996: Bacterial spoilage of meat and cured meat products. Int J Food Microbiol 33: 103-120

Devlieghere F, Debevere J 2000: Influence of dissolved carbon dioxide on the growth of spoilage bacteria. LWTFood Sci Technol 8: 531-537

Farber JM 1991: Microbiological aspects of modified-atmosphere packaging technology - a review. J Food Protect 54: 58-70

Gill CO, Harrison JCL, Penney N 1990: The storage life of chicken carcasses packaged under carbon-dioxide. Int J Food Microbiol 11: 151-157

Gram L, Ravn L, Rasch M, Bruhn JB, Christensen AB, Givskov M 2002: Food spoilage - interactions between food spoilage bacteria. Int J Food Microbiol 78: 79-97

HALASZ A, BARATH A, SIMONSARKADI L, HOLZAPFEL W 1994: Biogenic amines and their production by microorganisms in food. Trends Food Sci Tech 5: 42-49

Charles N, Williams SK, Rodrick GE 2006: Effects of packaging systems on the natural microflora and acceptability of chicken breast meat. Poultry Sci 85: 1798-1801

Chouliara E, Badeka A, Savvaidis I, Kontominas MG 2008: Combined effect of irradiation and modified atmosphere packaging on shelf-life extension of chicken breast meat: microbiological, chemical and sensory changes. Eur Food Res Technol 226: 877-888

Jeremiah LE, Gibson LL 2001: The influence of storage temperature and storage time on color stability, retail properties and case-life of retail-ready beef. Food Res Int 34: 815-826

Jimenez SM, Salsi MS, Tiburzi MC, Rafaghelli RC, Tessi MA, Coutaz VR 1997: Spoilage microflora in fresh chicken breast stored at 4 degrees C: influence of packaging methods. J Appl Microbiol 83: 613-618

Jimenez SM, Tiburzi MC, Salsi MS, Pirovani ME, Moguilevsky MA 2003: The role of visible faecal material as a vehicle for generic Escherichia coli, coliform, and other enterobacteria contaminating poultry carcasses during slaughtering. J Appl Microbiol 94: 65-72

Karovičová J, Kohajdová Z 2005: Biogenic amines in food. Chem Pap 59: 70-79

Malicki A, Bruzewicz S, Zechalko-Czajkowska A, Szybiga K, Kopec W, Trziszka T 2006: Comparison of the microbiological qualities of turkey myofibrillar protein isolate, mechanically recovered turkey meat and turkey breast. EJPAU 9(4), \#25. Available online: http://www.ejpau.media.pl/volume9/issue4/abs-25.html

Mielnik MB, Dainty RH, Lundby F, Mielnik J 1999: The effect of evaporative air chilling and storage temperature on quality and shelf life of fresh chicken carcasses. Poultry Sci 78: 1065-1073 
Min J, Lee S, Jang A, Lee M, Kim Y 2004: Production of biogenic amines by microflora inoculated in meats. Asian Austral J Anim 17: 1472-1478

Paulsen P, Bauer F, Vali S 1997: Biogenic amines in fermented sausage. 1. Methods for the determination of biogenic amines. Fleischwirtschaft 77: 450-452

Phillips CA 1996: Review: Modified atmosphere packaging and its effects on the microbiological quality and safety of produce. Int J Food Sci Tech 31: 463-479

Pin C, De Fernando GDG, Ordóñez JA 2002: Effect of modified atmosphere composition on the metabolism of glucose by Brochothrix thermosphacta. Appl Environ Microb 68: 4441-4447

Reddy NR, Armstrong DJ, Rhodehamel EJ, Kautter DA 1992: Shelf-life extension and safety concerns about fresh fishery products packaged under modified atmospheres - a review. J Food Safety 12, 87-118

Shalaby AR 1996: Significance of biogenic amines to food safety and human health. Food Res Int 29: 675-690

Silva CMG, Glória MBA 2002: Bioactive amines in chicken breast and thigh after slaughter and during storage at $4 \pm 1$ degrees $C$ and in chicken-based meat products. Food Chem 78: 241-248

Sivertsvik M, Jeksrud WK, Rosnes JT 2002: A review of modified atmosphere packaging of fish and fishery products - significance of microbial growth, activities and safety. Int J Food Sci Tech 37: 107-127

Sørheim O, Aune T, Nesbakken T 1997: Technological, hygienic and toxicological aspects of carbon monoxide used in modified-atmosphere packaging of meat. Trends Food Sci Tech 8: 307-312

Stiles ME 1991: Scientific principles of controlled/modified atmosphere packaging. In: Ooraikul B, Stiles ME (Eds.): Modified atmosphere packaging of food. Ellis Horwood Ltd., Chichester, England, pp. 18-25 and 118147

Susiluoto T, Korkeala H, Björkroth KJ 2003: Leuconostoc gasicomitatum is the dominating lactic acid bacterium in retail modified-atmosphere-packaged marinated broiler meat strips on sell-by-day. Int J Food Microbiol 80: $89-97$

Vihavainen E, Lundström HS, Susiluoto T, Koort J, Paulin L, Auvinen P, Björkroth KJ 2007: Role of broiler carcasses and processing plant air in contamination of modified-atmosphere-packaged broiler products with psychrotrophic lactic acid bacteria. Appl Environ Microb 73: 1136-1145

Vinci G, Antonelli ML 2002: Biogenic amines: quality index of freshness in red and white meat. Food Control 13: $519-524$

Zeitoun AAM, Debevere JM, Mossel DAA 1994: Significance of Enterobacteriaceae as index organisms for hygiene on fresh untreated poultry, poultry treated with lactic-acid and poultry stored in a modified atmosphere. Food Microbiol 11: 169-176 